\title{
PENGADAAN TANAH MELALUI PRANATA ADAT \\ DI PROVINSI BENGKULU \\ (Kajian Dalam Hukum Dan Ekonomi)
}

\author{
Imam Mahdi \\ Dosen Syariah IAIN Bengkulu \\ Jalan Raden Fatah Pagar Dewa Bengkulu \\ Email: Imam.mahdi@gmail.com
}

\begin{abstract}
Soil is the main thing in business in the plantation sector, but the way to obtain it is difficult because of the conditions. Between positive law and customary law in the way ownership of land by investor for plantation business will be an obstacle, HGU (Business Use Rights) issued by the government contain elements of legal certainty in positive law, while in absolute law over land, but the hereditary rights can not just disappear or go away. Land acquisition by investors through customary law will find obstacles in legal certainty, because it is difficult to later be slashed, sold and so on. The world of plantations is an economic world that can be traded.
\end{abstract}

Keywords: Land Acquisition, Customary Law

\begin{abstract}
Abstrak: Tanah merupakan hal yang pokok dalam usaha dibidang perkebunan, namun cara memperolehnya sukar yang dilatar belakangi karena kondisi. Antara hukum positif dan hukum adat dalam cara kepemilikan atas tanah oleh invetor untuk usaha perkebunan akan menjadi kendala, HGU (Hak Guna Usaha ) yang dikeluarkan oleh pemerintah mengandung unsur kepastian hukum dalam hukum positif, sementara dalam hukum mutlak atas tanah, melainkan hak turun temurun yang tidak bisa hilang atau lepas begitu saja. Pembebasan tanah oleh investor melalui hukum adat akan menemukan kendala dalam kepastian hukum, karena sulit nantinya untuk diborokkan, dijual dan sebagainya. Sementara dunia perkebunan adalah dunia ekonomi yang bisa diperjual belikan.
\end{abstract}

Kata kunci : Pembebasan Tanah, Hukum Adat 


\section{Pendahuluan}

Berdasarkan hasil penelitian Kusmito Gunawan $^{1}$ hampir pada setiap investasi perkebunan besar di provinsi bengkulu bermasalah terutama dalam hal pengadaan tanah bagi investor, gejala tersebut disebabkan oleh faktor insvertor sendiri yang ingin menerapkan ketentuan hukum yang berlaku secara umum sedangkan disisi lain masyarakat sekitar merasa "dirugikan" dengan adanya investasi tersebut, karena merasa tanah tanah mereka diambl oleh investor, padahal jika dikaji secara ekonom investor bukan ingin mencari tanah seluas-luasnya akan tetapi hasil dari tanah tersebut memberikan keuntungan bagi mereka. Dan bagi masyarakat sekitar perkebunan tersebut tidak hanya ingin menonton perkebunan yang hebat tetapi secerca harapan dengan adanya investor tersebut mendapatkan kesejahteraan dari tanah nenek moyangnya dan tanah tersebut suatu saat dapat diwariskan kepada anak cucunya dikemudian hari.

\section{Pembahasan}

Memasuki era globalisasi saat ini menimbulkan hubungan interdepedensi dan integrasi disemua bidang. Hal ini merupakan dampak dari globalisasi ekonomi tersebut. Yang mengembangkan prinsip liberalisasi yang dikembangkan secara bersama-sama oleh

\footnotetext{
Kusmito Gunawan, Faktor-Faktor Yuridis Penyebab Sengketa Tanah Pertanian Antar Investor Pemegang Hak Guna Usaha Versus Warga Masyarakat Di Kabupaten Bengkulu Utara, Laporan Penelitian Pada Fakultas Hukum (Bengkulu: Unib 2003) 134
}

negara-negara didunia. $^{2}$ Pengaruh tersebut juga terasa oleh daerah-daerah, sehingga setiap daerah harus mempunyai kemampuan dalam mengantisifasi gejala ini, salah satu faktor yang perlu disiapkan adalah perangkat hukum yang akan dipergunakan apabila berhadapan dengan transaksi investasi dunia luar. Peran hukum adalah salah satu diantara lembaga/pranata-pranata sosial. Seperti juga halnya keluarga, agama, ekonomi, perang atau lainnya. ${ }^{3}$

Hukum bagaimanapun sangat dibutuhkan untuk mengatur kehidupan bermasyarakat didalam aspeknya, apakah itu kehidupan sosial, kehidupan politik,budaya, pendidikan apalagi yang tak kalah pentingnya adalah fungsinya atau peranannya dalam mengatur kegiatan ekonomi. Dalam kegiatan ekonomi inilah justru hukum sangat diperlukan karena sumber-sumber ekonomi yang terbatas disatu pihak dan tidak terbatasnya permintaan atau kebutuhan akan sumber ekonomi dilain pihak sehingga konflik antara kepentingan dalam memperebutkan sumber-sumber ekonomi tersebut akan sering terjadi hal tersebut harus dikaji melalui hukum ekonomi baik hukum ekonomi sosial dalam antrian pengaturan cara-cara pembagian hasil pembangunan maupun dalam kajian hukum ekonomi pembangunan maupun dalam kajian

2 Bismar Nasution, Hukum Kegiatan Ekonomi, Dalam Era Globalisasi, (Bandung: Booksterace\& Library, 2005) h.1

T. Mulya Lubis, Ed.,Peranan Hukum Dalam Perekonomian Dinegara Berkembang, (Jakarta: Yayasan Obor Indonesia, 1986) h.119 
AL-IMARAH: Jurnal Pemerintahan dan Politik Islam Vol. 3, No. 2, 2018

hukum ekonomi pembangunan yang meliputi pengaturan peningkatan dan pengembangan kehidupan ekonomi indonesia ( peningkatam produksi ) secara nasional berencana. ${ }^{4}$ Disamping itu sesuai dengan potensi daerah dan dihubungkan dengan rencana percepatan pembangunan sektor perkebunan masih memberikan peluang untuk dikembangkan hal ini sesuai dengan kondisi geografis Provinsi Bengkulu.

Namun perlu dipahami terlebih dahulu landasan hukum bagi investor dibidang perkebunan besar pada saat ini. Didalam literatur perundang-undangan bidang model hukum masi berupa hak guna usaha yang diatur dalam undang-undang nomor 5 tahun 1960 (LN Tahun 1960 Nomor 104: TLN Nomor 2034) dari pasal 28 sampai dengan pasal 34. Ada beberapa pasal yang mempunyai potensi konflik ditengah masyarakat dati pengaruran UU tersebut yaitu : pertama pasal 28 ayat (1) menyebutkan " Hak Guna Usaha adalah hak untuk mengusahakan tanah yang dikuasai langsung oleh negara, dalam jangka waktu sebagaimana tersebut dalam pasal 29, guna perusahaan pertanian, perikanan atau peternakan" kemudian ayat (2) menyebutkan : Hak Guna Usaha diberikan atas tanah yang luasnya 5 hektar, dengan ketentuan bahwa jika luasnya 25 hektar atau lebih harus memakai investasi modal yang layak dan tekhnik perusahaan yang baik, sesuai dengan

4 CFG.Sunaryati Hartono, Hukum Ekonomi Pembangunan Indonesia, (Jakarta : Binacipta,1988), h.53 perkembangan zaman " ketentuan ayat (2) ini sangat kontradiktif dengan asas landreform bagi tanah pertanian untuk pertanian untuk petani yang mempunyai batas maksimal dan batas minimum terutama jika dikaitkan dengan pasal 7 UUPA yaitu : “ untuk tidak merugikan kepentingan umum, maka pemilikan dan pengesahan tanah-tanah yang menyebutkan : “ Hak Guna Usaha diberikan untuk waktu paling lama 25 tahun : ayat (2) untuk perusahaan yang memerlukan waktu yang lebih lama dengan diberikan hak guna usaha untuk waktu yang paling lama 35 tahun; ayat (3) atas permintaan pemegang hak dan mengingat keadaan perusahaannya jangka waktu yang dimaksudkan dalam ayat (1) dan ayat (2) pasal ini dapat diperpanjang dengan waktu paling lama 25 tahun adan sesudah masa tersebut berakhir dapat diajukan permohonan pembaharuan hak guna usaha kembali di atas tanah yang sama.

Objek hak guna usaha adalah tanah negara, yaitu tanah-tanah yang belum ada hakhak di atas tanah tersebut, sehingga pemerintah membuat kebijaksanaan dengan aturan pembebasan tanah yang objeknya tanah masyarakat baik hak ulayat maupun hak perorangan, disinilah pangkal sengketa penguasaan tanah.

Peraturan perundang-undangan yang terbaru di bidang perkebunan adalah undangundang nomor 18 tahun 2004 tentang perkebunan ( LN Tahun 2004 nomor 85 ; TLN 
Nomor 4411 ) Diatur pada Bab III dari pasal 9 sampai dengan pasal 12 , pengaturan hak guna usaha sama dengan aturan yang terdapat dalam UUPA. Undang-undang ini yang mengalami kemajuan adanya kemungkinan menggunakan perjanjian antara pengelola usaha perkebunan dengan pemegang hak ulayat, seperti diatur dalam pasal 9 ayat (2) yaitu : “ Dalam hal tanah yang diperlukan merupakan tanah hak ulayat masyarakat hukum adat yang menurut kenyataan masih ada, mendahului pemberian hak sebagaimana dimaksud pada ayat (1) , pemohon hak wajib melakukan musyawarah dengan masyarakat hukum adat pemegang hak ulayat dan warga pemegang hak atas tanah yang bersangkutan, untuk memperoleh kesepakatan mengenai penyerah tanah, dan imbalannya." Penjelasan pasal 9 ayat (2) masyarakat hukum adat yang menurut kenyataanya masih ada jika memenuhi unsur:

1. Masyarakat masih dalam bentuk paguyuban (rectsgemeinschaft)

2. Ada kelembagaan dalam bentuk perangkat penguasa data;

3. Ada wilayah hukum adat yang jelas;

4. Ada pranata dan perangkat hukum, khususnya peradilan adat yang masihditaati; dan

5. Ada pengukuhan dengan peraturan daerah

Dalam hal perpanjangan 25 tahun dari 35 tahun waktu maksimum juga ada kemajuan, seperti yang diatur dalam penjelasan pasal 11 ayat (2) pada intinya perpanjangan dapat diberikan jika ada keuntungan bagi pelaku usaha masyarakat sekitar dan negara.

Dari kajian perundang-undangan tersebut dapat kita bandingkan dengan modelmodel transaksi tanah yang ada ditengah masyarakat yaitu:

Pada umumnya transaksi pelepasan hak yang diatur dalam perundang-undangan adalah "perjanjian bagi hasil" seperti yang diatur dalam Undang-Undang nomor 2 tahun 1960 (LN Tahun 1960 nomor : TLN Nomor 1924 ) tentang perjanjian bagi hasil, yang mengatur khusus mengenai tanah pertanian, kemudian pada tahun 1964 dikeluarkan lagi undangundang nomor 16 tahun 1964 tentang bagi hasil (LN Tahun 1964 Nomor 97; TLN Nomor 2690 ).

Menurut boedi harsono, keluarnya UU ini dalam rangka untuk melindungi golongan petani ekonomis lemah terhadap praktekpraktek golongan yang kuat yang mengandung unrur-unsur "exploitation”, dalam masa jabatan Menteri Agraria Sadjarwo....”

Didalam mengkaji model-model transaksi yang berhubungan dengan tanah berlaku di masyarakat dapat dikemukakan seperti pendapat soeryono. Pada transaksi tanah bukan menjadi objek seperti transaksi tanah, akan tetapi hanya mempunyai hubungan dengan tanah, misalnya: 
AL-IMARAH: Jurnal Pemerintahan dan Politik Islam Vol. 3, No. 2, 2018

a. Memperduai (Minangkabau ) ,Maro, Martelu (Jawa), Nengah (Jawa,Sunda) Tesang (Sulawesi Selatan) Dan Tayo (Maluku) transaksi memperduai (maro) konstruksinya adalah jika pemilik tanah memberikan izin kepada orang lain untuk memperkerjakan tanah itu denga perjanjian bahwa yang mendapat izin harus memberikan sebagian (separo) hasil tanah kepada pemilik tanah.

b. Sewa tanah dalam arti tertulis mempunyai transaksi tersendiri (afzonderlijke overeenkomst), yang mengizinkan olrang lain untuk memperkerjakan tanahnya dengan membayar sesudah setiap panen atau sesudah etiap bulan atau setengah tahun, uang sewa yang tetap.

c. Maro atau sewa bersama-sama dengan gadai kontruksinya dalah sebagai berikut: A( yang menerima tanah yang digadaikan) segera memberikan izin kepada si B (pemilik tanah) untuk mengerjakan tanah itu dengan transaksi atau sewa.

d. Tanggungan (zakerheidsstelling), dasar transaksi ini adalahs elama hutang belum dibayar, saya tidak membuat perjanjian tentangtanah saya kecuali dengan memberikan uang (credeteuir). Transaksi ini disebut : Tanggungan. Jonggoloan (Jawa), Tahan (Batak) Mahkhanta (Bali). e. Numpang (Bogwonen,Opwonen), jika seorang pemilik tanah mempunyai tanah diatas tanah itu yang didiami sendiri, memberi izin kepada orang lain untuk membuat rumah (ditanah itu) yang ia diami sendiri.

Menurut imam Sudiyat ${ }^{5}$ transaksi yang bersangkutan dengan tanah dapat dibedakan sebagai berikut:

1) Transaksi bagi hasil belah pinang,paruh haisil tanaman;

2) Sewa

3) Kombinasi bagi hasil serta sewa dengangadai tanah dan sewa tanah dengan pembayaran uang muka

4) Transaksi pinjam uang dengan tanggungan tanah;

5) Simulatio, perbuatan pura-pura, schijnhandellin.

Di Provinsi Bengkulu, tansaksi-transaksi seperti sewayaitu sorang atau sorongan Yang berlaku di Kabupaten Rejang lebong dan sekitarnya. Hasil penelitian Emilia Kontesa dan kawan-kawan menunjukan bahwa di Kabupaten Rejang Lebong ada transaksi ( perjanjian ) yang konstruksinya sebagai berikut : " pemilik tanah terlantar (belum diusahakan) menyerahkan atau meminjamkan tanahnya kepada pekerja untuk digarap menjadi lahan kebun kopi dalam jangka waktu tertantu, setelah jangka waktu tertent, setelah

Iman Sudiyat, Hukum Adat sketsa asas, (Yogyakarta Liberty,1981) h.37-50 
jangka waktu perjanjian selesai, maka lahan

kebun kopi produktif harus dikembalikan kepada pemilik tanah..."6

Menurut peneliti pranata sorongan dikenal di daerah kecamatan Kepahyang Rejang Lebong, akan tetapi berdasarkan literatur yang ada pranata ini tidak hanya berada di Kecamatan Kepahyang namun menyebar hampir keseluruh Kabupaten Rejang Lebong, seperti Kecamatan Padang Ulak Tanding dan sebagainya.

Pengkajian terhadap pranata adat yang berlaku di Provinsi Bengkulu khususnya dan di Nusantara pada umumnya harus digunakan metode kearipan lokal yaittu mengkaji hukum dalam kehidupan mayarakat, maka hukum dipandang merupakan bagian dari kehidupan sosial budaya suatu kelompok masyarakat yang masih sederhana (tradisional) maupun masyarakat yang sudah kompleks (modern) seperti masyarakat di daerah perkotaan sekarang ini. ${ }^{7}$

Dalam mengkaji aturan hukum transaksi-transaksi seperti pranata-pranata di atas yang berlaku ditangah masyarakat harus melalui pendekatan hukum adat setempat. $^{8}$

${ }^{6}$ Emilia Kontesa,Dkk , Model Perjanjian Sorong Melalui Pranata Sorong Dalam Pemeliharaan Keentraman Dan Ketertiban Kehidupan Masyarakat Miskin Perambah Hutan Di Daerah Terpencil Dan Terisolir, (Laporan Penelitian, Fakultas Hukum Universitas Bengkulu,2001), h.iii

${ }^{7}$ Andry haryanto. H ,Bahan Kuliah Hukum An Kearifan Lokal, Program Pasca Sarjana Ilmu Hukum UNIB , Semerter III.

${ }^{8}$ Hukum adat setempat: yaitu ketentuan hukum adat yang berlaku di daerah yang bersangkutan pada waktu terjadinya kasus yang akan diselesaikan atau pada waktu diperlukan untuk menyelesaikannya. Hal ini berkaitan dengan 138
Biasanya para ahli hukum dalam pendekatan antropologi hukum, karena norma-norma hukum adat ditinjau sebagai kebudayaan, dan melalui metode ini hukum dikaji secara lebih luas, seperti dikemukakan oleh andry: "konsep hukum menurut antropologi itu dipergunakan untuk megkaji hukum secara lebih luas, yaitu hukum sebagai gejala atau proses sosial dalam kajian ini hukum tidak hanya dilihat sebagai konsep yang mengandung unsur pemaksa dan otoritas negara seperti yang ada pada hukum positif nasional, melainkan juga hukum lain seperti hukum agama, hukum adat dan norma-norma lain yang berlaku dalam kehidupan masyarakat."

Sedangkan pranata-pranata yang telah diformalkan dikaji melalui hukum positif dengan berpedoman kepada aturan-aturan yang telah dibuat oleh lembaga Negara/pemerintah. Tetang hak-hak ini sebagian UUPA mengatur tentang hak-hak transaksi ini seperti pada pasal 16, yang akan dikemukakan pada pembahasan ini adalah pasal 16ayat (1) huruf h, yaitu " hak-hak lainnya tidak termasuk dalam hak-hak yang sifatnya sementara seperti yang disebutkan pada pasal 53:

pasal 56 UUPA yang intinya tentang pengaturan hak milik seperti yang diatur pada paSal 20 UUPA maka yang diberlakukan adalah hukum adat, kemudian pasal 58 mengenai pengertian bumi dan air serta kekayaan alam yang terkandung di dalamnya serta hak-hak atas tanah diberlakukan hukum adat.

9 Andry Haryanto Hartiman, Antropologi Hukum, (Lemlit Unib Press 2001) h. 11 
Pasal 53 ayat (1) menyebutkan : " hakhak yang sifatnya sementara sebagai yang disebut pasall 16 ayat (1) huruf h, ialah hak gadai, hak usagha bagi hasil, hak numpang dan hak sewa tanah pertanian diatur untuk membatasi sifat-sifatnya yang bertentangan dengan undang-undang ini dan hak-hak tersebut diusahakan hapusnya didalam waktu yang singkat."

Khusus hak gadai termuat dalm undangundang nomor 56 PP tahun 1960 tentang penepatan luas tanah pertanian (L.N Tahun 1960 Nomor 174 ; TLN Nomor 2117) pasal 1 ayat (1) menyebutkan :" barang siapa menguasai tanah pertanian dengan hak gadai yang pada waktu mulai berlakunya peraturan ini sudah berlangsung 7 tahun lebih wajib mengembalikan tanah itu kepada pemiliknya dalam waktu sebulan setelah tanaman yang ada selesai dipanen, dengan tidak ada hak untuk menuntut pembayaran uang tebusan “ dalam penjelasan umum disebutkan alasan penghapusan gadai ini karena berpedoman kepada kenyataan yaitu dalam praktiknya hasil tanah yang diterima oleh pemegang gadai adalah jauh melebihi bunga yang layak dari pada uang pinjamannya".

Kemudian Menteri Pertanian dan Agraria mengeluarkan keputusan nomor SK.10/Ka/1963 tanggal 1 maret 1963 tentang penegasan berlakunya pasal 7 Undang-Undang Nomor 56/1960 Bagi Gadai Tanaman Keras yang intinya tanaman keras yang digadaikan, berikut atau tidak tanahnya harus dikembalikan kepada pemilik tanah.

Tentang hak-hak yang lain yang disebutkan pada pasal 16 ayat (1) huruf h, tersebut masih diberi status sementara, karena dianggap tidak sesuai dengan hukum tanah nasional, salah satu asas penting penting dalam hukum tanag nasional ialah, bahwa boleh dalam usaha-usaha dibidang pertanian tidak boleh ada pemerasan , tidak boleh terjadi apa yang disebut " exploitation de I hommer " ( pasal 11 ayat 1$){ }^{10}$

Model-model transaksi terhadap tanah adat, dapat dimodifikasi sesuai dengan kesepakatan keduabelah pihak, karena sifat dari masyakat hukum adat itu selalu dinamis bergerak dengan kemajuan zaman " sekali ayiah gadang sakali tapian baranjak" arti hukum adat tidak mesti mempertahankan yang masih menghambat perkembangan masyarakat itu sendiri. Sebagai contoh perjanjian sorong melalui pranata sorongan di Kabupaten Rejang Lebong telah dibuat trtulis dan dituangkan dalam akta perjanjian sorong sebagai akta autentik melibatkan sistem kepemimpinan informal (tradisional) dan sistem kepemimpinan formal (pemerintah desa dan kecamatan).

Sesuai dengan tuntutan globalisasi ekonomi, dan konsekuensi dari keterlibatan

10 Boedi Harsono. Sejarah, Hukum Agraria Indonesia, Sejarah Pembentukan Undang-Undang Pokok Agraria Isi Dan Pelaksanaannya. (Jakarta: Djambatan, 1999) h 293-294 
indonesia sebagai salah satu diantara 125 negara yang ikut menandatangani perjanjian WTO yang lahir sebagai hasil perundingan putaran uruguawai (uruguay round) yang diselengarakan dalam rangka general agreeement on trip on trade (GATT) yang berbasis kepada perdagangan bebas dengan landasan untuk mencapai pertumbuhan ekonomi pembangunan dan kesejahteraan umat manusia. ${ }^{11}$ Oleh karena itu diperlukan hukum ekonomi sebagai pranata hukum yang berisi seperangkan aturan untuk memberikan antisipasi ekonomi indonesia di era globalisasi, model-model transaksi adat tadi dapat dijadikan solusi dalam memenuhi tuntutan guna menampung aturan-aturan perdagangan global dan regional.

Seperti pranata sorong atau sorongan, justru akan menguntungkan kedua belah pihak, karena pihak insvertor tidak perlu mengeluarkan modal yang sangat besar untuk mendapatkan lahan perkebunan,karena lahan didapat melalui suatu kontrak bagi hasil, dan masyarakat petani tidak perlu takut akan kehilangan tanah perkebunan tersebut karena investor hanya ingin mendapatkan hasil usahanya tidak berkeinginan menguasai tanah tersebut.

\section{Penutup}

1. Pranata hukum adat yang masih berlaku dimasyarakat Bengkulu seperti sorong, yang terdapat di

\footnotetext{
${ }^{11}$ Bismar Nasution, Hukum ....h. 8
}

Kabupaten Rejang Lebong dan sekitarnya dapat di jadikan alternatif sebagai pengganti hak-hak atas tanah warisan penjajah yang justru tidak memberikan keadilan pada masyarakat pranata adat yang berkaitan dengan hak penguasa tanah secara Yuridis dapat di pertanggungjawabkan, dan secara sosiologis dan psikologis sangat menguntungkan kedua belah pihak.

2. Keberpihakan pemerintah tehadap masyarakat petani sangat mendukung upaya-upaya mempercepat peningkatan kesejahteraan masyarakat keberpihakan itu tidak hanya dalam tataran aksional sesaat tetapi secara terus menerus dilakukan, hal ini dapat terwujud jika ada peraturan perundang-undangan yang benar-benar berihak kepada masyarakat miskin.

3. Salah satu penyebab penolakan oleh masyarakat petani terhadap investasi perkebunan besar, karena sistem kepemilikan tanah yang di terapkan oleh investor yang terobsesi dengan keinginan menguasai tanah dan mendapatkan keuntungan yang sebesar-besarnya dengan dalih kepastian hukum terhadap tanah tersebut, kepada kauntungan bersama dengan bukan berorientasi pada masyarakat sekitar. 
AL-IMARAH: Jurnal Pemerintahan dan Politik Islam

Vol. 3, No. 2, 2018

4. Keinginan investor dalam kepemilikan tanah di selesaikan melalui hukum positif adalah untuk kepastian hukum dalam upaya memperbesar usaha untuk dapat diborohkan kepada pihak lain, seperti pinjam kepada bank atau jual saham.

\section{Pustaka Acuan}

Kusmito Gunawan, Faktor-Faktor Yuridis Penyebab Sengketa Tanah Pertanian Antar Investor Pemegang Hak Guna Usaha Versus Warga Masyarakat Di Kabupaten Bengkulu Utara, Laporan Penelitian Pada Fakultas

Hukum (Bengkulu: Unib 2003)

Bismar Nasution, Hukum Kegiatan Ekonomi, Dalam Era Globalisasi, (Bandung: Booksterace\& Library, 2005)

T. Mulya Lubis, Ed.,Peranan Hukum Dalam Perekonomian Dinegara Berkembang, (Jakarta: Yayasan Obor Indonesia, 1986)

CFG.Sunaryati Hartono, Hukum Ekonomi Pembangunan Indonesia. (Jakarta : Binacipta,1988)

Iman Sudiyat, Hukum Adat sketsa asas, (Yogyakarta: Liberty,1981)

Emilia Kontesa,Dkk , Model Perjanjian Sorong Melalui Pranata Sorong Dalam Pemeliharaan Keentraman Dan Ketertiban Kehidupan Masyarakat Miskin Perambah Hutan Di Daerah Terpencil Dan Terisolir, (Laporan
Penelitian, Fakultas Hukum Universitas Bengkulu,2001)

Andry haryanto. H ,Bahan Kuliah Hukum An Kearifan Lokal, Program Pasca Sarjana Ilmu Hukum UNIB , Semerter III.

Andry Haryanto Hartiman, Antropologi Hukum, (Lemlit Unib Press 2001)

Boedi Harsono. Sejarah, Hukum Agraria Indonesia, Sejarah Pembentukan Undang-Undang Pokok Agraria Isi Dan Pelaksanaannya. (Jakarta: Djambatan, 1999) 